\title{
Rømø dine læger
}

af JOHANNES BRIX

Mellem 1864 og 1920 var der mange problemer med at sikre det nødvendige lægetilsyn på øen Rømø, som lå i den yderste udkant af det tyske rige. Lægerne skiftede hurtigt, og efter 1898 opstod der problemer mellem det tyske badested Lakolk og lægerne. Læge Johannes Brix, Aabenraa, fortæller her om Romøs læger frem til Genforeningen, især om dr. Voswinkel, som også blev kendt som fremragende fotograf på øen.

Talrige læger har virket på Rømø i tiden før Genforeningen. Kun få navne er almindeligt kendt i dag. De fleste har kun været på kortvarige ophold uden at have slået rod, ingen havde nogen tilknytning til egnen. Med en enkelt undtagelse kom de fra helt andre regioner af det tyske rige, og deres virke er forblevet næsten anonymt. I korte biografier vil der $\mathrm{i}$ det folgende blive redegjort for deres virke og for nogle af de problemer, lægerne kom ud for.

Det skinner igennem adskillige af disse ufuldstændige og korte biografier, at det ofte var personer med en speciel og vanskelig baggrund, som søgte deres udkomme på øen, og de fleste var der kun en kort periode. Badeanstalten i Lakolk kunne have været en supplerende indtægtskilde for lægerne, men blev det ikke. Ydermere skinner det igennem flere af biografierne, at der var nationale modsætninger, der gjorde det svært for nogle læger at falde til på øen.

I den anden halvdel af artiklen lægges hovedvægten på at beskrive Theodor Voswinkel, der har været den læge, der har virket længst på øen. Interessen samler sig især om Voswinkels tvist med myndighederne, der kan samles til to hovedemner. Det ene var de mildest talt problematiske overenskomstmæssige forhold for ølægen. Dette måtte i sagens natur blive sammenfiltret med hans strid med og næsten ultimative uvilje mod ledelsen af badet i Lakolk. Hans animositet mod badet bundede i personlig uvilje mod badets ledelse, men tillige mod den politik, der blev fort fra officiel side i forhold til badets eksistens. Man kan roligt sige, at hans uvilje nærmest blev en passion. Embedsmændene har tydeligvis været ude af stand til at tackle de regler og bestemmelser, der var gældende for lægers virke. Dette sam- 
menholdt med, at de læger, der kom til øen, havde en vidt forskellig baggrund for netop at søge et så ensomt embede, har gjort samarbejdet mellem myndighed og læger meget vanskeligt.

\section{Lægerne}

Lægerne var ikke de første sygdomsbehandlere på Rømø, idet kirurger allerede havde virket på øen fra begyndelsen af 1800-tallet. Vor biografiske viden om lægerne er yderst begrænset og bygger som regel kun på deres ansøgninger, der kan findes i arkiverne. Imidlertid overholder de færreste de almindelige former for en ansøgning, og indholdet svarer som regel slet ikke til det, man i stillingsannoncer forventede.

Den første læge, der blev ansat på øen var Peter Michelsen Jochimsen (1807-1879). Han var født i Abild ved Tønder og virkede på øen fra 1858 til sin død som 71-årig. Han boede i en mindre, angiveligt faldefærdig ejendom på Østerhede. Jochimsen havde bestået lægeeksamen i Kiel 1834 og var derefter blevet lic.med. samme sted. Han havde, før han kom til Rømø, fra 1834 til 1858 virket i Løgumkloster og havde derfra vikarieret for forskellige distriktskirurger på Rømø i deres fravær. Han må således have kendt til de økonomiske kår på øen, da han tiltrådte stillingen. Han bliver i flere sammenhænge beskrevet som godmodig og uden større initiativ. Han fungerede som læge helt til sin død.

De økonomiske vilkår som læge på Rømø var de ringest tænkelige. Da Peter Michelsen Jochimsen døde, udsendte fysikus i Tønder Christian Heinrich Schlaikjer (1824-1879) ${ }^{1}$ en skrivelse til kollegerne i Tønder og Haderslev fysikatsdistrikt med anmodning om at samle ind til den efterladte enke, der efter skrivelsens ordlyd var så fattig, at hun end ikke var i stand til at give sin mand en standsmæssig begravelse. Han anfører endvidere i sin skrivelse, at Jochimsens faste løn havde været 270 Mark og med ekstraindtægter måske ikke nåede op på mere end 370 Mark, hvilket efter tidens målestok var en meget lille indtjening for en læge.

Efter Jochimsens død var man ikke i stand til straks at få genbesat stillingen. Det var derfor meget betydningsfuldt, da der kom en skrivelse fra landråden $i$ Tønder dateret den 27 . marts 1880 til herredsfogeden i Visby ${ }^{2}$, i hvilken han meddeler, at han fra "Ministerium für Unterricht und Medizinalangelegenheiten« havde modtaget den be- 


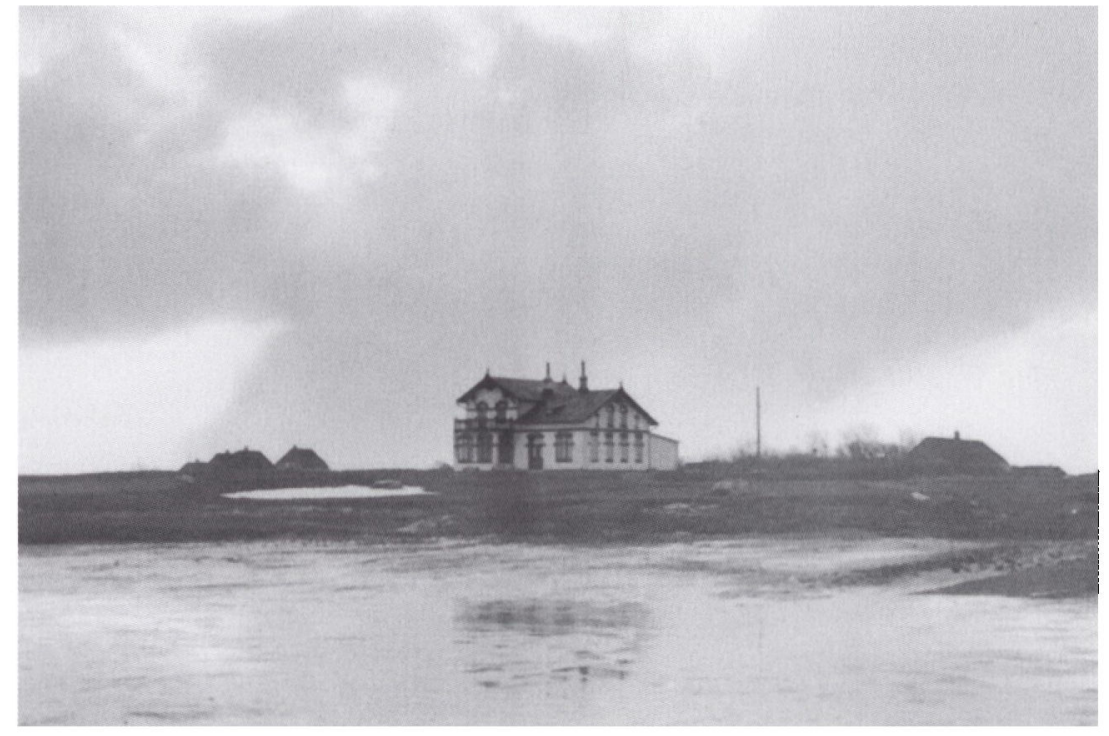

Billedet viser den fritliggende lægebolig $i$ Kongsmark. Byggeriet stod fxrdig til indflytning $i 1904$ og kostede 9.000 rigsmark. Huset rummede en firevarelseslejlighed samt lægepraksis. Denne omfattede bl.a. en konsultationsstue, et venteværelse samt et lille rum til apoteksudsalget. Af husets ca. $100 \mathrm{~m}^{2}$ var de 74 privatbolig. Foto $i$ Institut for sønderjysk lokalhistorie.

sked, at staten fra 1 . april 1881 var villig til at betale et årligt beløb på 600 Mark til en læge, der havde til hensigt at nedsætte sig på øen. Imidlertid var hertil knyttet den betingelse, at øboerne gav et tilskud af tilsvarende størrelse. Dette blev accepteret af Rømø-beboerne.

Den første læge, der nød godt af denne nye aflønning var dr. Pfalzgraf (1822-1893), der i den fremskredne alder af 59 år den 1. februar 1881 skrev kontrakt med kommunerne på øen og derpå virkede på øen indtil 1887. Det viste sig dog ikke at være så let, hverken for øboerne eller den nyankomne læge, at komme på bølgelængde med hinanden. Ret hurtigt kom Pfalzgraf på konfrontationskurs med nogle af øboerne. Efter at der var indløbet flere klager til herredsfogeden i Visby udarbejdede denne efter samtaler med befolkningen en rapport til landråden i Tønder. ${ }^{3}$ I denne blev der gjort rede for øboernes animositet mod Pfalzgraf. Det blev således nævnt, at dr. A. F. Nagel (1856-1937) ${ }^{4}$ fra Højer afholdt konsultation på øen. Hans besøg tiltrak mellem 30 til 40 patienter i konsultationen hver gang, han kom. 
Den ret omfattende redegørelse indkredsede følgende tre hovedpunkter som årsag til kritikken af Pfalzgraf:

1) Pfalzgraf holdt sig ikke til de gængse takster, som alle kendte, men han havde tilsyneladende helt sine egne, som øboerne havde svært ved at gennemskue.

2) Han tog sjældent hensyn til småkårsfolks og tjenestefolks begrænsede økonomiske ressourcer ved beregningen af honoraret.

3) Han havde et iltert temperament.

Løsningsforslaget gik ud på, at Pfalzgraf skulle bøje sig for befolkningens ønsker om at føre en mere forståelig takstpolitik og tage de nødvendige sociale hensyn. Det fremhæves specielt, at man ingen hjemmel havde, der kunne forhindre, at der i perioder kom en anden læge til øen. Det nævnes sluttelig, at øboerne var som øboer plejede at være, - lidt vanskelige. Man overvejede at opsige kontrakten med Pfalzgraf, hvilket dog efter al sandsynlighed ville have medført, at stillingen ikke var blevet genbesat. Pfalzgraf forlod af egen fri vilje øen i 1887.

Pfalzgraf blev 1887 efterfulgt af dr. Abraham Mendel, der var jøde og født i Friedrichstadt. Han kom fra en stilling i Hofgeismar, og virkede på øen indtil sin død 8. maj 1893.

Mendels efterfølger blev dr.med. Louis Halter (1858-1894), der tiltrådte stillingen medio august $1893 .{ }^{5}$ Halter opnåede at blive meget afholdt af befolkningen. Han blev begravet på øen.

I sommersæsonen 1893 virkede dr.med. Paul Ponath fra Kallies i Pommern på Rømø. Han forlod øen igen i midten af september for at tage til Osnabrück. Han havde imidlertid fået løn for hele måneden, så landråden satte alt ind på at få den for meget udbetalte løn tilbage. Da det havde lange udsigter med at få pengene retur, solgte kommunerne ved en auktion de mobler, Ponath havde efterladt. Det beløb, der derved indkom, blev modregnet $i$ hans, efter øboernes mening, for meget udbetalte løn.

Efter dr. Ponaths afrejse var det ikke muligt straks at få en ny læge til øen. Man annoncerede flittigt, og der var også læger, der reflekterede på stillingsopslagene. Således holdt kommunerne møde i Kongsmark den 24. august, 12. september, 20. oktober og 17. december 1894, hvor der hver gang efter votering blev valgt en læge, men ingen tiltrådte stillingen. 


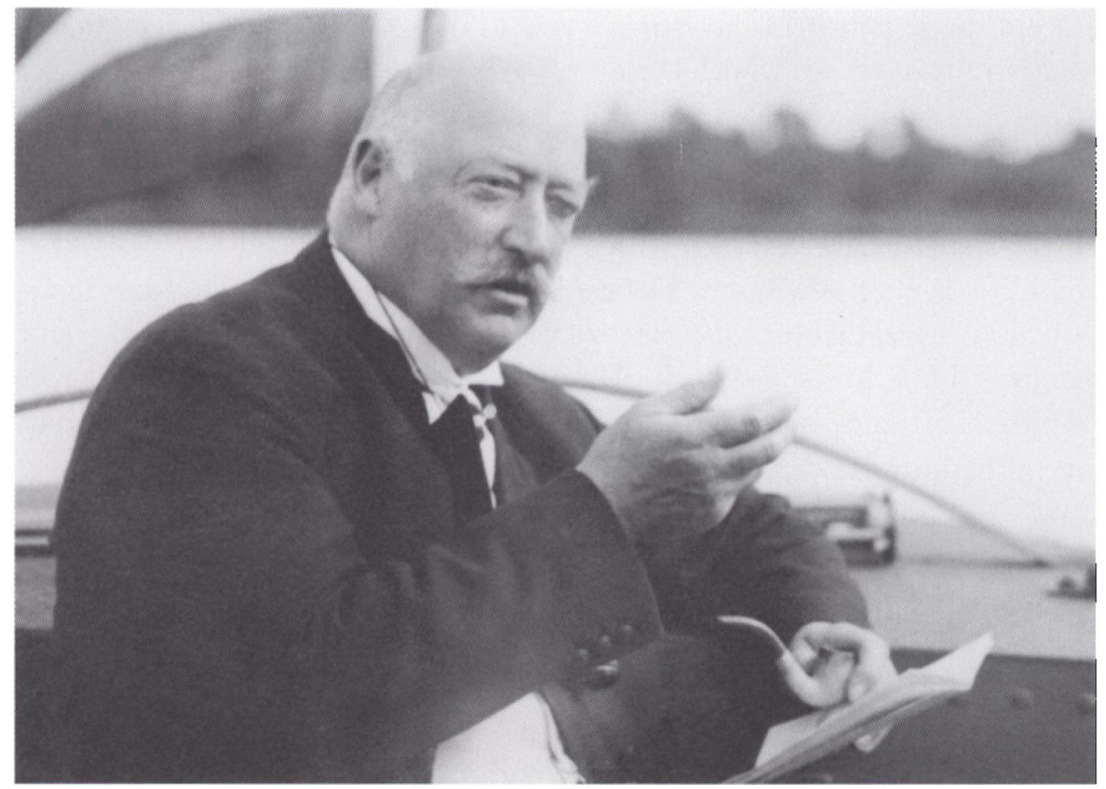

Landråd $i$ Tonder Friedrich Rogge (1867-1932). Rogge var præstesøn og blev $i$ sin tid $i$ Tonder fra 1904 til 1914 en kyndig og afholdt embedsmand også $i$ danske kredse. Efter Genforeningen fortsatte han den administrative løbebane $i$ Slesvig-Holsten. Foto $i$ Institut for sonderjysk Lokalhistorie.

Først den 15.oktober 1895 tiltrådte den praktiserende læge dr. C. B. Schlesinger stillingen på øen. Han kom fra Ostenfeld i nærheden af Münster, men også han rejste kort efter igen.

I 1897 annoncerede "Amtsbezirk Röm « i aprilnumret af »Berliner Klinische Monatsschrift « atter efter en læge, der kunne tænke sig at nedsætte sig på Rømø. Der var denne gang fire ansøgere til stillingen, blandt hvilke man valgte dr. Klamroth. Stillingen blev nu finansieret ved sammensatte bidrag, således kom der 600 Mark fra »Königliche Steuerkasse" og 900 Mark kom fra »Amtsbezirk Röm«. Endvidere fik han som bolig overladt en ejendom, som han skulle betale en årlig husleje på 130 Mark for, hvilket var en fordelagtig pris set fra myndighedernes side. Klamroth tiltrådte stillingen den 28. maj 1897 og blev indtil 1. oktober $1899 .^{6}$

Klamroth skulle vise sig at give anledning til adskillige problemer. Han var således den første læge, der kom til at samarbejde med badeanstalten i Lakolk. 
I en lille brochure "Das Nordseebad Lakolk auf Röm " fra 1899 står Klamroth anført som badelæge i Lakolk, som potentielle badegæster kunne henvende sig til, såfremt de havde spørgsmål vedrørende kurog badeopholdet.

Klamroth ønskede allerede efter kort tid at forlade øen, idet han var af den opfattelse, at det iflg. hans kontrakt var muligt med kort varsel at opsige stillingen. Denne fortolkning delte amtsforstanderen dog ikke og repræsentanterne fra Rømø protesterede og mente, der forelå et klart kontraktbrud, såfremt han rejste med det korte varsel på nogle få uger, han havde givet. Man fremhævede således, at han havde forladt øen flere gange uden at sikre øboerne en lægelig betjening i sit fravær. Amtsforstanderen tilskrev Klamroth, at man som en selvfølge gik ud fra, at Klamroth i sit fravær ikke virkede som læge andetsteds og oppebar honorar ved siden af.

I talrige korrespondancer med amtsrådet redegjorde Klamroth for årsagerne til, at han ikke ønskede at forblive på øen og hurtigst muligt ville forlade den. Han fremførte således som en meget betydningsfuld hændelse en sag, hvor en kvindelig patient $i$ hans øjne ganske uberettiget havde klaget over den lægelige behandling, hun havde fået. Endvidere anførte han som noget meget væsentligt, at hans bolig i Kirkeby i alle henseender var utilfredsstillende.

I sommeren 1898 havde "Kreisarzt" dr. Otto Horn (1848-1916) fra Tønder foretaget uanmeldt revision af Klamroths medicinbeholdning. ${ }^{7}$ Det viste sig, at der var kaos i bogføringen, og at medicinen delvis var for gammel eller $i$ en sådan tilstand, at alene indtagelsen af medicinen måtte anses for at kunne medføre sygdom. Dette var Klamroth ligeledes blevet brystholden over.

Det kan undre, at en læge med baggrund som mangeårig militærlæge og lange udenlandsophold søgte sin første civile stilling på Rømø, der i sagens natur var ganske anderledes end hans hidtidige stillinger. Det hele yderligere garneret med nationale modsætninger.

For at oboerne ikke skulle komme til at stå helt uden læge efter Klamroths afrejse, entrerede man derefter med dr. Riis fra Højer, der tilså patienterne i den vakante periode mod særskilt betaling. ${ }^{8}$

Efter nogen vakance tiltrådte dr. Hafermann, der på det tidspunkt virkede i Berlin. Her havde "Kreisarzt « Otto Horn fra Tønder mødt ham i marts 1899 efter anbefaling af den tidligere nævnte professor Vilhelm Nagel.

Hafermann tiltrådte sin stilling den 10. oktober 1899. Han var født 
i Ostfriesland. Den faste løn var nu steget til 1800 Mark årligt. Han opsagde sin stilling til fratræden den 1. oktober 1903, men forlod allerede øen i 1902. Ved sin tiltræden fik han stillet en bolig til rådighed, men boede det meste af tiden hos private eller på gæstgiverier, idet han anså den bolig, Amtsbezirk Röm havde udset til ham for at være for ringe. Dette synspunkt gav anledning til en del skærmydsler med myndighederne.

Hafermann indgik kontrakt den 20. oktober 1899. Den 22. maj 1900 blev hans kontrakt revideret derhen, at han fik ret til at holde et husapotek, således at han kunne behandle akutte medicinske tilfælde. Hafermann løb ind i nogle problemer, der hidrørte fra leveringen af det husapotek, han havde bestilt ved en leverandør i Hamborg. Hafermann havde aftalt, at denne tillige skulle levere medicinen. Dette kunne kredsen ikke godtage, idet medicinen skulle bestilles ved det lokale apotek i Skærbæk. Dette medførte nogen fortrydelighed hos Hafermann.

Ydermere oplevede Hafermann at modtage en klage fra de pårørende til en afdød patient. Her havde eksekutor klaget over den medicinpris, boet skulle betale Hafermann. Den lå over den aktuelle takst ved andre apoteker, mente klageren. Medicinen havde desuden beviselig været ganske uden virkning, anførte eksekutor sarkastisk i sin skrivelse. Hafermann virker meget seriøs i sin argumentation for sin prisfastsættelse, men enden på sagen blev, at man i amtsrådet delvis gav klageren ret. Hafermann forlod øen i dyb frustration. Han praktiserede senere i Dedelsdorf i Holsten. Men det blev vistnok heller ingen succes. I 1905 var han nemlig blandt ansøgerne til stillingen som ølæge efter Otto Gerber. Han har åbenbart haft et stort ønske om at tiltræde stillingen, idet han anfører, at han var i stand til at vikariere i starten, før han tiltrådte stillingen. Hafermann fik ikke stillingen.

Hafermanns efterfølger i 1902 blev dr. Ludwig Otto Popke, der i en kortere periode virkede som vikar på øen. ${ }^{9}$ Han tiltrådte stillingen som ølæge den 2. november 1902. Efter ca. 6 måneder forlod han imidlertid øen og flyttede til Flensborg.

Fra 1903 til 1905 virkede dr. Hugo Kalweit på Rømø som »Landschaftsarzt «. Han blev valgt blandt hele 10 ansøgere og var den første, der flyttede ind i den nye lægebolig som var opført i Kongsmark. Kalweit fik ved sin tiltræeden tilladelse til at holde husapotek, der dog skulle visiteres af apoteker Simon O. E. Rafalski fra Skærbæk Apotek. ${ }^{10}$ Der skulle ikke gå lang tid, før han klagede over uheldige for- 
hold i den nybyggede lægebolig. Bygningen var iflg. hans opfattelse meget utæt og af samme årsag var det nærmest umuligt at opvarme huset på tilfredsstillende vis.

Kalweit var den første formand for sundhedskommissionen, der hvert år efter badesæsonens afslutning skulle give en indberetning til kredslægen om bl.a. de hygiejniske forhold vedrørende badet $i$ Lakolk. ${ }^{11}$ Kalweit havde, før han tiltrådte stillingen på Rømø været ved militæret og blev i april 1905 genindkaldt for at gøre tjeneste ved ekspeditionskorpset $i$ Sydvest Afrika. Han meddelte derfor amtsforstanderen, at han opsagde sin stilling med virkning fra 1 . april 1905.

Kalweits efterfølger blev dr. Theodor August Gerber, der underskrev kontrakt med henblik på at tiltræde stillingen som læge på Rømø 15. juli 1905. Lægens faste salær var nu steget til ialt 2000 Mark årlig. ${ }^{12}$ Han tiltrådte stillingen i en forholdsvis fremskreden alder af 65 år. Gerber fik i januar 1906 et slagtilfælde, hvorpå han opsagde sin stilling.

Det skal nævnes, at man i stillingsopslaget ved Gerbers fratræden havde betegnet stillingen som "Amtsbezirksarzt «, hvilket umiddelbart kunne virke meget tilforladeligt, da Rømø udgjorde et »Amtsbezirk « og at stillingsbetegnelsen måske også signaliserede noget fornemmere. Den centrale tyske lægeforening meddelte derfor amtsforstanderen på Rømø, at den læge, der tiltrådte en stilling som Amtsbezirksarzt, skulle have bestået »Physikatseksamen«. Alene dette ville gøre det lidet sandsynligt, at der ville være ansøgere til stillingen. Men, og det oplyste man samtidig, ifald der alligevel skulle være ansøgere, så var lønnen også en ganske anden, end den i annoncen anførte. I den næste annonce var stillingsbetegnelsen ændret til "Landschaftsarzt«.

Ved et møde som sundhedskommissionen afholdt i Lakolk 18.7. 1906 under ledelse af kredslæge Horn blev det besluttet, at lægen på Rømø fremover automatisk tillige skulle være formand for sundhedskommissionen ved badet i Lakolk. ${ }^{13}$ Samtidig blev det fastlagt, at badedirektionen i Lakolk skulle give en særskilt indberetning til kredslægen (Kreisarzt) i Tønder med henblik på driften af badet.

Indtil dette tidspunkt var der så vidt vides ikke større problemer mellem badet i Lakolk og de nævnte læger, der alle beredvilligt virkede som »badelæger« i sæsonen og derved tjente lidt ekstra, selv om tilstrømningen på ingen måde var overvældende. Endvidere var de 
Theodor Voswinkel var fodt i Rhin-provinsen i 1864 og blev lage $i$ 1890. Han tiltrådte stillingen som landskabslege pà Rømø $i$ 1906, men forlod 1921 Røme for at bosætte sig $i$ Keitum på naboøen Sild. Han dode $i$ 1946. Foto $i$ Institut for sønderjysk lokalhistorie.

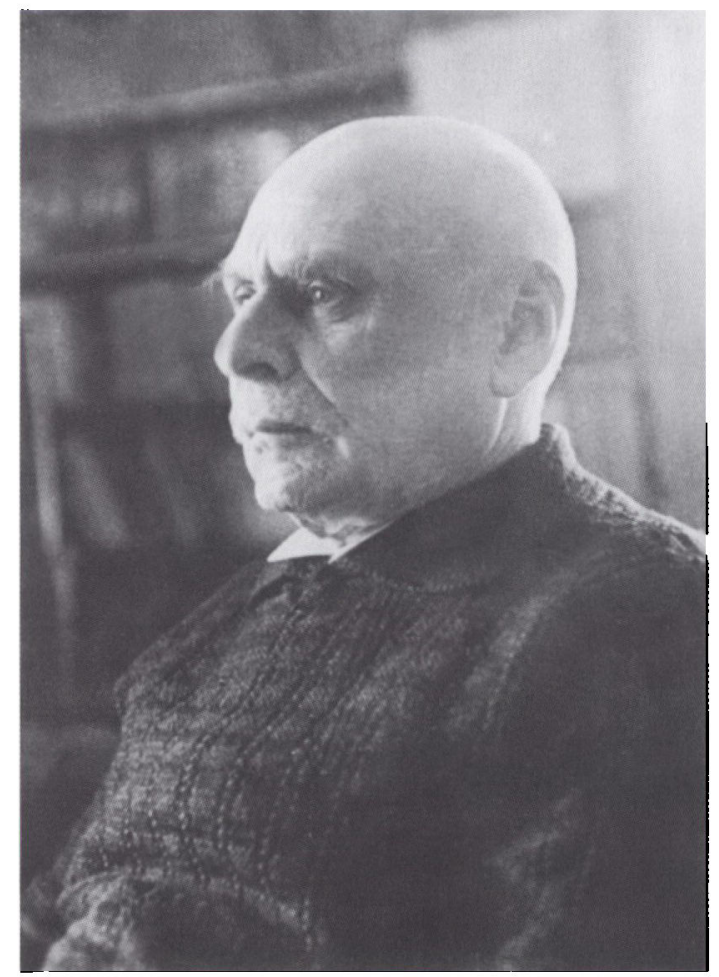

medlem af den lovpligtige sundhedskommission. Problemerne opstod imidlertid med den følgende læge.

Da man skulle vælge Gerbers efterfølger, var der hele 10 ansøgere til stillingen. ${ }^{14}$

Man valgte dr. Theodor Voswinkel (1864-1946) som tiltrådte allerede i maj 1906. Hans ansøgning var meget kortfattet. Det fremgår dog, at han var 42 år, at han blev læge i 1890. Han havde ikke promoveret. Voswinkel var af evangelisk religion og ugift. Han oplyser i en bisætning, at han havde haft en praksis i provinsen Hannover, men ønskede at flytte til Berlin i nærheden af sin bror. Imidlertid lykkedes det ham ikke at overtage den af ham ønskede praksis i Tegel, en lille forstad til Berlin. Af denne årsag søgte han stillingen på Rømø. Voswinkel havde lidt forhåndskendskab til Rømø.

Af andre kilder fremgår det, at han var født i Diebach ved St. Goar i Rhinprovinsen. Voswinkel virkede på øen indtil 1921, hvorefter han 
flyttede over til naboøen Sild og bosatte sig i Keitum. Voswinkel var en ivrig fotograf og har efterladt en hel række interessante fotografier som delvis er benyttet som illustrationsmateriale i denne fremstilling.

\section{»Nordseebad Lakolk auf Röm G.m.b.H.»}

Der er skrevet en del om Lakolk som badested, især i relation til grundlæggeren, pastor Chr. Johs. Jacobsen (1854-1919) i Skærbæk og den store konkurs som i 1903 ramte hans mange erhvervsmæssige aktiviteter $\mathrm{i}$ og omkring Skærbæk. I den forholdsvis korte tid, badestedet eksisterede, kom dette til at betyde en del for de læger, der virkede på øen. Af denne grund vil det kort blive omtalt.

Selve badet »Nordseebad Lakolk auf Röm G.m.b.H.«blev åbnet den 15 . juli 1898 under megen festivitas ${ }^{15}$. Allerede fra starten var der

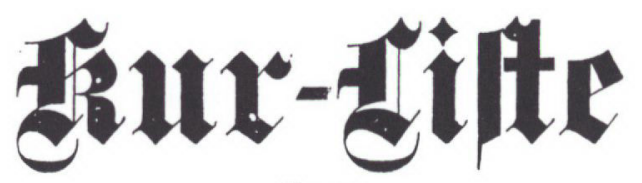

fiir oas
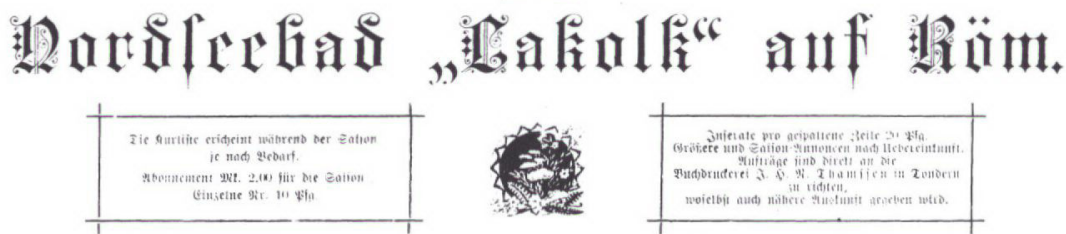

Foransacteben won oer 23 abcleituma in Sterrebet.

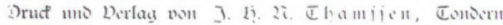

\begin{tabular}{|c|c|c|c|}
\hline \multicolumn{3}{|c|}{ żorbfeebao sakofk auf æäm, ben 14. ¿̀tti 1899.} & tifig. \\
\hline $2 t a \mathrm{ac}$ & $5 t a n o$ & $w \circ \downarrow n \circ r t$ & $\begin{array}{l}\text { Pit } \\
\text { font } \\
\text { jaly }\end{array}$ \\
\hline 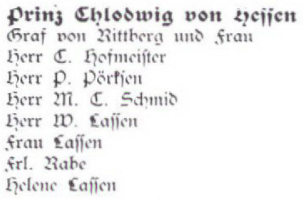 & $\begin{array}{c}\text { (1)ifficer } \\
\text { Evibjüger } \\
\text { Kaufthant } \\
\text { 23antworitanto }\end{array}$ & 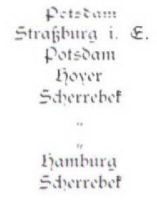 & $\begin{array}{l}1 \\
2 \\
1 \\
1 \\
1 \\
1 \\
1 \\
1 \\
1 \\
1\end{array}$ \\
\hline
\end{tabular}

"Nordseebad Lakolk« udgav fra 1899 en Kurliste. Her kunne man bl.a. få oplysning om nyankomne kurgæster. Privateje. 
røster fremme $\mathbf{i}$ tyske kredse om det nærmest umulige $\mathbf{i}$ at forvente, at et kur/badested ville kunne overleve økonomisk, især når man tog hensyn til dets beliggenhed langt fra storbyernes store befolkningsmasser og så ovenikøbet ret isoleret ved Rømøs vestside. Ydermere var de trafikale forhold med henblik på at komme til øen og videre frem til Lakolk meget vanskelige og på ingen måde afklaret, da badets bygninger stod færdige.

Hele kurstedet var dimensioneret stort, idet bebyggelsen fra begyndelsen omfattede 35 blokhuse, der senere blev oget til over 40. Disse fik et karakteristisk udseende, som i betydelig grad afveg fra den på øen gængse byggestil. Endvidere byggede man gæstgiveriet "Römerhof «.

Rekreationsstedets målgruppe var først og fremmest den tyske mellemklassefamilie. Af samme grund opkrævede man heller ikke "Kurtaxe", der ellers var almindelig ved lignende anlæg andetsteds.

Et indtryk af besøgstallet på Rømø de første år får man af følgende optælling:

$\begin{array}{lc}\text { År } & \text { Antal gæster } \\ 1898 & 30 \\ 1899 & 1106 \\ 1900 & 1853 \\ 1901 & 2072 \\ 1902 & 1667^{16}\end{array}$

Af disse var i 19001283 og i 19011136 på Rømø mindre end tre døgn. Efter 1901 dalede besøgstallet. Disse besøgstal var alt for ringe til, at investeringen kunne give et rimeligt afkast. Når man tager året 1901 som udgangspunkt, var husene i gennemsnit kun udlejet mindre end to måneder om året. ${ }^{17} \mathrm{I}$ de sidste par år før udbruddet af 1 . Verdenskrig var antallet af badegæster kun på 200 til 300 pr. sæson. ${ }^{18}$

Pastor Jacobsens aktiviteter var kapitalkrævende. Han opnåede ved agitationsvirksomhed blandt medlemmerne af Den tyske Forening i det nordlige Slesvig og medlemmerne af Det altyske Forbund i det øvrige Tyskland at få betydelige pengebeløb stillet til rådighed. ${ }^{19}$

\section{Dr. Voswinkel i strid med Lakolk}

Der skulle ikke gå lang tid efter, at Voswinkel var ansat som læge på Rømø, før han kom i konflikt med offentlige myndigheder. Landråd 
Rogge i Tønder meddelte amtsforstander Freytag i Bredebro, at den nyudnævnte landskabslæge på Rømø ved sin tiltræden den 15. juni 1906 var udnæunt til formand for sundhedskommissionen på Rømø. ${ }^{20}$ Halvanden måned efter sin tiltræden i maj 1906 meddelte $\mathrm{dr}$. Theodor Voswinkel imidlertid, at han ønskede sig fritaget for embedet som formand for sundhedskommissionen i Lakolk. ${ }^{21}$ Dette var en alvorlig sag for badet, idet loven som tidligere nævnt krævede, at der var en fungerende sundhedskommission ved hvert badested. Som årsag for ønsket om at blive fritaget for hvervet anførte Voswinkel, at der var et meget dårligt samarbejdsklima mellem direktionen for badet i Lakolk og ham selv.

Han blev mere konkret i en skrivelse til amtsforstander Freytag en måneds tid senere. ${ }^{22}$ I denne redegjorde han for en hændelse i Lakolk. Her var et barn, der havde lungetuberkulose pludselig død af en "Lungenblutung«. Barnet var død inden Voswinkel kunne nå at komme til Lakolk. Han kunne således reelt intet stille op for at redde barnet. Dette var naturligvis en forfærdelig hændelse for barnets forældre, men det var tillige en dramatisk oplevelse for badets øvrige gæster. Badedirektionen har muligvis set sin eksistens truet ved, at der var indtrådt et dødsfald på stedet, specielt da badet atter var ude i endog store økonomiske problemer. Direktøren havde udtalt sig nedsættende om Voswinkels lægelige virke og formåen overfor det afdøde barns forældre. Dette havde faderen derpå nævnt i en samtale med Voswinkel, der straks opsøgte badets direktør, som iflg. Voswinkel under hele samtalen stod med begge hænder i sine bukselommer og dermed viste sin despekt. Direktøren fremførte i løbet af denne samtale ligeledes negative påstande om Voswinkels lægelige virke. Voswinkel understregede i flere omgange, at han iflg. landråd Rogges eget udsagn ikke var forpligtet til at tilse badegæsterne.

Medens ovenstående tragiske oplevelse var alvorlig nok, så har Voswinkels nøgleoplevelse formentlig været af mere banal art. Den indtraf efter at han kun havde opholdt sig få dage på Rømø. Voswinkel var blevet tilkaldt af direktionen for badet til en patient, der angiveligt havde forstuvet sit fodled og ikke kunne komme $i$ Voswinkels konsultation med lokalbanen til Kongsmark. Direktionen havde derfor foranlediget, at Voswinkel blev afhentet tidligt på aftenen for at tilse patienten i Lakolk. Da Voswinkel arriverede, var patienten ikke til at opdrive og man mente, at damen var gået en tur i den skønne sommeraften. Voswinkel henvendte sig til direktionen 
at Voswinkel efter få dage ophørte med at afholde den daglige konsultation i Lakolk, og at han havde ytret onske om at blive fritaget for at skulle behandle badegæsterne der.

At Voswinkels modstand mod badet var konsekvent kan således bl.a. ses deraf, at en skrivelse fra direktionen til Voswinkel var blevet returneret, idet adressaten, dvs. Voswinkel, nægtede at modtage den. Hermed var tonen mellem direktionen for badet i Lakolk og Voswinkel angivet i de næste mange år.

Som anden årsag til sin utilfredshed nævner Voswinkel, at han havde en del udestående for nogle konsultationer i Lakolk i 1906, som direktionen ikke agtede at betale. Derfor ophørte han med at afholde konsultationer i Lakolk. Desuden mente han, at det var "eine grosse Dreistigkeit", at der i prospektet for badet i Lakolk 1907 var anført, at der fandtes en badelæge i Lakolk. Han forbeholdt sig ret til, juridisk at få korrigeret dette forhold $\mathrm{i}$ brochuren ved fremtidige genoptryk. Han forstod sig som øboernes læge og ikke andet. Han var dog villig til at tilse syge gæster på øen såvel som badegæster, såfremt han blev tilkaldt direkte. Han afslog således pure at have noget med badets direktion at gøre.

\section{Et spørgsmål om takt, takst og tone}

I løbet af sommeren 1907 blev tonen skærpet. Således nævnte landråd Rogge i en skrivelse til Voswinkel af 18.7.1907, at det var hans opfattelse, at Voswinkels tone overfor de offentlige myndigheder var på grænsen af det acceptable. Rogge bekræftede dog, at Voswinkel havde ret, når han anførte, at han kun var ansat til at tilse oboerne og at behandlingen af de tilrejsende badegæster var et mellemværende mellem gæsterne og Voswinkel. ${ }^{24}$ Men om dette forhold burde der dog kunne opnås enighed, således at badegæsterne ikke kom til at lide under den igangværende konflikt. Rogge benægtede på det bestemteste, at der skulle være lagt politisk pres på Voswinkel med henblik på at betjene badegæsterne i Lakolk.

Voswinkel nævner i flere omgange over for amtsforstanderen de efter hans opfattelse meget ringe økonomiske forhold, han virkede under. ${ }^{25}$ Således anfører han, at han ved overtagelsen af stillingen skulle betale 1200 Mark for forgængerens efterladte medicin, selv om apotekeren i Skærbæk Simon O. E. Rafalski havde vurderet den til kun at være 400 Mark værd. I den stillingsannonce, han havde reflek- 
teret på, var der blevet stillet $\mathrm{i}$ udsigt, at han ville kunne opnå en årlig indtægt på 5000 Mark. Reelt var den det første år kun blevet til 3000 Mark. Endvidere havde han et udestående beløb ved badeanstalten i Lakolk, som det ikke var muligt for ham at få inddrevet.

I takt med at striden eskalerede, henvendte Voswinkel sig til lægesammenslutningen »Leipziger Verband der Ärzte« for at få støtte i sin kamp mod myndighederne. I et efterfølgende brev til amtsforstander Freytag, dateret 18.7.1907, skriver han, at hans indtægter i det forgangne år havde ligget under det, han havde forventet. Han mente derfor, at det ville være meget vanskeligt at få besat stillingen på Rømø, med mindre der blev indgået en aftale med lægesammenslutningen. Han anforer til sidst $i$ brevet, at han er blevet opfordret til at opsige sin stilling, men nævner dog samtidig flere punkter som betingelse for at fortsætte i stillingen. Den første betingelse var, at han skulle have mere i løn, dernæst skulle honoraret for første gangs ydelser forhøjes. Desuden skulle der ske en forbedring af lægeboligen. Endvidere skulle det være muligt for lægen at forlade øen uden at skulle stille en vikar, da dette i realiteten var umuligt.

Situationen synes at være tilspidset, idet der også fra regeringspræsidenten i Slesvig findes flere korrespondancer til landråden i Tønder med henblik på at få løst konflikten. Amtsforstanderen i Bredebro plæderer voldsomt for at få en afklaring omkring landskabslægens ansættelsesforhold. Ved et mode i Lakolk den 21.7.1907 besluttede kommunerne på Rømø sig for at opsige den kontrakt, man havde indgået med Voswinkel. Årsagen til dette skridt var, at pårørende til amtsforvalter Freytag, der var badegæster på Lakolk, havde konsulteret Voswinkel p.g.a. et forvredet fodled og modtog et honorarkrav, som man mente var ublu. Voswinkel forsvarede sig med bl.a. at angive prisen for sine konsultationer, nemlig 5 Mark for en konsultation i Kongsmark og 20 Mark for et sygebesøg i Lakolk. Disse honorarkrav svarede til dem, man opkrævede i Tyskland efter aftale med Leipziger Ärztebund. ${ }^{26}$

For de medarbejdere, der var ansatte på badet i Lakolk var der ingen problemer med at blive betjent af lægen i Kongsmark, idet disse enten var medlemmer af sygekassen i Tønder eller andre sygekasser og det lægelige honorar blev opkrævet efter de aftaler, der var indgået med disse sygekasser.

Man var klar over, at ølægens økonomiske stilling ikke var den bedste, hvilket ses af korrespondancen mellem landråden og rege- 
Billedet viser troljevognen trukket af en hest på vej gennem klitterne. Linjeforingen gik fra Lakolk til Kongsmark. Driften blev pábegyndt kort efter badets indvielse og fortsatte frem til 1940. Foto i Institut for sonderjysk lokalhistorie.

ringspræsidenten i Slesvig med henblik på at få honorarerne forhøjet. I disse overvejelser indgik, at man skulle pålægge Nordseebad Lakolk G.m.b.H. et fast bidrag for, at patienterne kunne få konsultationer i Lakolk. Et beløb på 200 Mark blev nævnt. I en skrivelse til landråden fra 24.8.1907 melder badets direktion hus forbi, idet dets økonomi angiveligt var så anstrengt, at det ikke ville være i stand til at betale et fast lægehonorar for sine gæster.

Tonefaldet mellem regeringspræsidenten og Voswinkel eskalerer i en skrivelse af 28.7.1907, hvor Voswinkel meddeler, at han ikke vil indgå en aftale med direktionen for badestedet i Lakolk. Selv Freytag måtte dog have konstateret, skriver han, at det ikke er muligt at blive enig med Lakolks »Hoteldirektor (einem Oberkellner)«. Han mener dog, at det ville være muligt at indgå en aftale med badet i Lakolk, men kun såfremt der skete en udskiftning af direktionen. Han skriver "... es kann von einem anständigen Arzte nicht verlangt werden, dass er mit einem Menschen in Berührung tritt, der alle Eigenschaften eines Kellners untüchtigster Sorte in sich vereinigt « ${ }^{27}$

Herefter er der ro i en længere periode. I et meget langt brev til landråden i Tønder skriver Voswinkel, at badet, der efter hans opfat- 
telse var statslig finansieret, ved sin holdning havde ruineret den krovært, der drev »Römerhof «, der iflg. Voswinkel på bemærkelsesværdig måde forfægtede sin tyske holdning uden hensyn til kommercielle interesser. Forholdene på øen var blevet helt utålelige, efter at badet i Lakolk havde fået en ny inspektør, en hr. Friedemann. Om sit forhold til befolkningen på Rømø skriver Voswinkel, at han egentlig var glad for sin stilling som landskabslæge på øen, især fordi han havde et uproblematisk forhold til øboerne. Såfremt man overhovedet fremover ønskede at have en læge på øen, måtte man indstille sig på, at de fremtidige kontrakter blev indgået efter gængse regler. ${ }^{28}$

Regeringspræsidenten i Slesvig optog herefter kontakt til repræsentanter for lægesammenslutningen og stillede i udsigt, at de ville få ændret det sidstnævnte forhold snarest. Voswinkel indvilligede midlertidigt i at fortsætte sit virke på øen, indtil man havde fået en afklaring på de nævnte ankepunkter hhv. fundet en afløser.

Det lykkedes imidlertid ikke kredsen at få besat stillingen, idet man forgæves annoncerede både i lægetidsskrifter og i dagblade i Berlin. Der synes at have været en aftale om, at samtlige stillingsopslag $i$ Tyskland skulle gå gennem et centralbureau i den tyske lægeforening.

Imidlertid blev Voswinkel ikke formildet over for badedirektionen, idet han $i$ august $1908 \mathrm{i}$ et brev til landråden skriver, at han havde haft besøg af den nye inspektør på badet i Lakolk, men at denne "durch seine Rohheit allgemein bekanntes Individuum wird zu entfernen sein, sonst werde nach meinem eventuellen Abgang von Röm die Sperre über die Insel verhängt werden «. ${ }^{29}$

En udløber af striden mellem Voswinkel på den ene side og amtsforstanderen og borgmestrene på Rømø på den anden side var, at Voswinkel i foråret 1907 havde bedt en repræsentant for Leipziger Ärzteverband i Slesvig-Holsten om at se på sin kontrakt, som han havde indgået med Amtsausschuss. Voswinkel mente, at aftalen var »standesunwürdig ${ }^{30}{ }^{30}$ I svaret gennemgås paragrafferne enkeltvis og i næsten alle tilfælde anses de som værende utidssvarende. Selve årsagen til betænkningen fra lægeforeningen, nemlig Voswinkels strid med badedirektionen i Lakolk, blev afgjort derhen, at Voswinkel ifølge den indgåede kontrakt ikke var forpligtet til at tilse badegæsterne. I øvrigt anfører lægeforeningen dog, at Voswinkels tone i denne sag nok kunne give anledning til nogen kritik. Udover de rent overenskomstmæssige punkter nævner man som et andet betydningsfuldt punkt, at amtsrådet ikke havde set sig i stand til at få tømt lægeboligens kloset, hvilket man anså 
som fuldstændig uværdigt. Voswinkel overvejede i flere omgange at opsige sin stilling, men tog ikke skridtet fuldt ud.

Efter at der således i næsten hele 1907 havde bølget en strid mellem Voswinkel på den ene side og på den anden side badet $i$ Lakolk og myndighederne, faldt den lidt til ro, men har åbenbart ulmet under overfladen. Voswinkel ændrede ikke holdning og i 1908 blussede fejden op igen.

I sine skrivelser til landråd Rogge, der meget pikant var formand for Den tyske Forening og derfor også var involveret i de økonomiske rekonstruktioner af badet i Lakolk, lægger Voswinkel ikke fingrene imellem, idet han skriver, at Lakolk er blevet et fristed for altyskere, der her på et øde sted frit kan udfolde sig uden for lov og ret. "Damit der Witz aber auch nicht hier fehlt, die Rechnung bezahlt der Staat « ${ }^{31}$

\section{Den såkaldte skandale}

I badesæsonen 1908 oplevede man atter et dramatisk højdepunkt. I en telegrafisk meddelelse til regeringspræsidenten i Slesvig dateret den 28.7.1908 skriver en ingeniør T. P. Lau fra Berlin: »Landschaftsarzt Voswinkel verweigert entschieden den Lakolker Badegästen seine Hilfe. Bitte um sofortige Drahtantwort«. Lau skriver, at der på Rømø herskede en chokeret stemning, efter at den delvis statslig finansierede læge Voswinkel i Kongsmark havde afvist to angiveligt meget syge patienter. Den ene var en dame, der var blevet stukket $i$ hånden af et insekt, hvorefter hånden var begyndt at hæve. Hun havde henvendt sig til Voswinkel i Kongsmark, men var blevet afvist.

Det andet tilfælde var et barn, der dagen efter ovenstående hændelse havde skåret sig på nogle glasskår i klitterne og blødte (Schwer verletzt!) Der blev sendt et bud til Voswinkel i Kongsmark. Lau skriver, at Voswinkel måtte lide af forfølgelsesvanvid, da han skal have sagt "... er könne nur mit einem geladenen Revolver nach Lakolk kommen und dies wolle er nicht«.

\section{Afskeden, der ikke blev til noget}

Voswinkel opsagde herefter sin stilling, men skiftede hurtig mening og ønskede nu at fortsætte i embedet, selv om det var faldet ham svært at trække sin afskedsansøgning tilbage. Som årsag til dette skridt anfører han, at lærerne Petersen og Jensen havde opsøgt ham 
og viderebragt et ønske fra øboerne om, at han forblev på øen. Han skriver "... wo werde ich je wieder einem solchen Beweis gütiger und freundlicher Gesinnung begegnen. Es ist das beste und schönste Erlebnis meiner bisherigen ärztlichen Laufbahn. Ich gebe mich der Hoffnung hin, dass ich einen Modus finden werde, bleiben zu können «. ${ }^{32}$

I administrationen var man meget vel klar over, at man ikke havde mange kort at spille med i forholdet til Voswinkel, der gennem det aktive engagement af lægeforeningen havde reduceret myndighedernes sanktionsmuligheder over for Voswinkel. Således var regeringspræsidenten i Schleswig blevet gjort opmærksom på, at Verband der Ärzte Deutschlands direkte frarådede deres medlemmer at søge stillingen på Rømø. ${ }^{33}$

Der blev fra centralt hold i de tyske lægeforeninger forhindret, at kommunerne kunne indrykke annoncer om stillinger på Rømø. ${ }^{34}$ Årsagen hertil var, at Voswinkel atter havde henvendt sig til lægeforeningen og bl.a. havde fremhævet, at der i stillingsopslaget var nævnt indtægtsmuligheder op til 5000 Mark. I virkeligheden havde indtjeningen som før nævnt dog kun ligget på omkring 3000 Mark. Voswinkel havde specielt nævnt, at det ikke var billigere at bo på øen, tværtom. De fleste varer skulle fragtes over til øen hvilket medførte, at varerne blev dyrere end på fastlandet.

Et fornyet stridsobjekt var den i 1908 nyudnævnte direktør for badet i Lakolk en hr. Friedemann. Denne person var helt åbenbart en torn i øjet på Voswinkel. Han truede således i en skrivelse til amtsforstander Thye med at opsige sin stilling, idet han kort meddeler, at han ønskede at fratræde sin stilling. Som årsag anførte han, at badet i Lakolk åbenbart ikke "... dem Lakolker Geist so innig verwandten Friedemann fallen lassen will, ich aber mit diesem Subjekt auf die Dauer nicht Haus an Haus wohnen kann«.

Få måneder senere kunne landråden meddele Voswinkel, at Friedemann fratrådte stillingen til den 31 . december $1908 .{ }^{35}$ Dette blev langt om længe udgangspunkt for mere fredelige forhold.

\section{Den fredelige slutning}

Voswinkels udfald mod badet i Lakolk havde været voldsomme, men landråden måtte i flere sammenhænge erkende, at Voswinkels forhold til øboerne var ganske uproblematisk, og myndighederne havde indtryk af, at han var vellidt. 
Voswinkel fik bekræftet, at han ikke var forpligtet til at drive praksis i Lakolk og det heller ikke kunne komme på tale, at man i kredsdagen i Tønder ville ændre Voswinkels kontrakt derhen, at man ville pålægge ham behandling af badegæster i Lakolk. På den anden side skulle Voswinkel heller ikke afvise at behandle patienter, der tilfældigvis opholdt sig i Lakolk. Konklusionen var således, at behandlingen af patienter i Lakolk var en privat sag mellem ham og patienterne. ${ }^{36}$ I en skrivelse kort tid efter meddeler Voswinkel landråden, at han var villig til at forlænge sin kontrakt som ølæge og at han også $\mathrm{nu}$, hvor forholdene i Lakolk havde forbedret sig, var villig til at behandle badegæster på Rømø.

I den tid, Voswinkel har været på Rømø, var der som tidligere beskrevet forekommet adskillige konkurser og betydelige delvis offentlige midler var af prestigemæssige og nationale årsager puttet i badet. Dette synes at have været en torn i øjet på Voswinkel. Hans tone og holdning overfor badet i Lakolk var uforandret negativ.

Efter at der i flere år kun synes at have været en meget formel og uproblematisk korrespondance mellem myndighederne og Voswinkel, kom der igen i 1912 en kurre på tråden. I en brochure annoncerede badet i 1912 med, at der var knyttet en badelæge til badet. Voswinkel protesterede. Badets daværende helt nye direktion forsvarede sig med, at stridighederne mellem Voswinkel og badet lå flere år tilbage og således ikke burde give anledning til fornyet strid, da forholdene nu var gode. Landråden blev på opfordring af Voswinkel nødsaget til at meddele badet, at Voswinkel kun var ansat til at betjene øens indbyggere. Dermed var ny uro afværget.

\section{Epilog}

Genforeningen medførte også personelle forandringer på Rømø. Således meddelte Voswinkel landråden i Tønder i juli 1919, at han af politiske årsager ønskede at forlade øen efter afståelsen til Danmark og han forespurgte, hvordan han skulle forholde sig i denne situation. Så vidt man kan se, fik han ikke noget svar.

Voswinkel fik et mangeårigt ophold på Rømø, knap 16 år, i modsætning til næsten alle tidligere læger, og disse år kom på afgørende måde til at præge forholdene på det medicinske område på øen op til Genforeningen. Forholdet på øen var præget af, at en så lille administrativ enhed som »Amtsbezirk Röm« havde endda meget svært 
ved at håndtere de problemer, som lægerne på øen gav anledning til. At det alligevel ikke gik helt galt skyldes, at landråden i Tønder som regel fik styr på tingene, når det var endt i totalt kaos på øen.

Korrespondancerne mellem Voswinkel og myndighederne afslører en konflikt mellem to divergerende opfattelser i den tyske lejr af, hvordan man skulle forholde sig overfor det konkursplagede bad i Lakolk.

Medens man i tyske kredse lagde stor vægt på at opretholde badet, så Voswinkel meget mere nuanceret på sagen. Han ankede især over det store offentlige pengespild, der var knyttet til de talrige økonomiske rekonstruktioner. Voswinkel var af den opfattelse, at statens penge kunne bruges meget bedre andetsteds, end til et prestigeprojekt, et bundløst kar, der i hans øjne var dømt til at kuldsejle. Vanskelighederne skyldtes efter hans mening det ansatte personales uduelighed og i ligeså høj grad, at filosofien bag badet ikke duede. Han understreger gentagne gange, at man under ingen omstændigheder ville kunne forvente en markant "germaniseringseffekt «, hvilket vist nok var det overordnede formål med at bruge offentlige midler til badet. Ud fra denne synsvinkel får Voswinkels strid med badedirektionen i Lakolk nye facetter og et nyt og interessant aspekt.

\section{KILDER OG NOTER}

Anm.: De biografiske oplysninger er indsamlet fra vidt forskellige kilder, ofte af lokalhistorisk art. De mere udferlige er baseret på de oplysninger der er givet i stillingsansøgningerne. Ansøgningerne findes i landsarkivet i Aabenraa, Rømø amtsforstanderarkiv, 301: Sager vedr. Læger paa Rømø.

Om kirurger på Romø kan læses i Johannes Brix' artikel "Kirurger på Rømø«, i: Sonderjysk Månedsskrift 1997 s. 45-48.

1. Christian Heinrich Schlaikjer var fodt i Egernsund, hvor faderen var teglværksejer. Han blev student i Haderslev 1845. Efter studier ved forskellige tyske universiteter bl.a. Heidelberg afsluttede han sin uddannelse i Kiel, hvor han blev dr.med. 1851. I tiden op til eksamen havde han deltaget i Treårskrigen som frivillig medicinsk student på den slesvig-holstenske side. Han praktiserede $\mathrm{i}$ nogle år $\mathrm{i}$ Egernsund, men flyttede derpå til Tønder. Her blev han den 30.7.1864 udnævnt til fysikus (embedslæge). Han døde $i$ Tonder som 54-årig den 24.11.1879.

2. Rømø hørte administrativt til Visby herredsfogderi fra 1867. I 1871 delte man oen op i tre kommuner, nemlig Juvre, Kirkeby og Kongsmark. Ved en administrativ reform i provinsen Slesvig Holsten 1.4.1889 kom Rømø til at udgøre et "Amtsbezirk«. Amtsforstanderen hørte administrativt under landråden i Tønder.

3. Tønder Landrådsarkiv, 209, Medicinal - kadsyn: $M$ 105: Skrivelse fra herredsfogeden $i$ Visby til landråden $i$ Tønder af 7. april 1885. 
4. Vilhelm A. F. Nagel (1856-1937) var født i Højer. Han voksede op i et stærkt dansk præget hjem. Faderen P. E. Nagel (1816-1890) var apoteker i Højer. V. A. F. Nagel blev student fra Sorø Akademi, men studerede og promoverede til dr.med. i Tyskland. I en kortere periode fra 1879 til 1885 virkede han som praktiserende læge $i$ Højer. Det er i denne periode, han også tilså patienter på Rømø. Han attråede imidlertid en mere videnskabelig løbebane og uddannede sig ved flere af tidens mest kendte tyske gynækologiske afdelinger. Han blev professor i Berlin 1896. Hans lærebøger fik stor udbredelse og han opnåede ry som en af tidens mest anerkendte gynækologer. Han havde gennem hele sit liv en tæt kontakt til hjemstavnen og var aktiv i det danske foreningsliv i Berlin. Nagel ligger begravet på kirkegården i Højer, hvor graven endnu eksisterer.

5. Louis Halter (1858-1894) havde efter studentereksamen påbegyndt medicinstudiet i Berlin og senere studeret i Marburg og afsluttede sin uddannelse i Greifswald, hvor han blev dr.med. 1881. Herefter virkede han ved en række forskellige sygehuse, indtil han i 1889 nedsatte sig som praktiserende læge på øen Usedom.

6. Klamroth var født den 16.2 .1865 som søn af en præst. Efter sin studentereksamen i 1884 var han frivillig ved Kaiser Alexander Garde Grenadier Regiment Nr. 1 i tiden fra 1.4. til 30.11.1885. Han påbegyndte efterfølgende medicin studiet ved universiteterne i Greifswald, Leipzig og Kiel, hvor han bestod lægeeksamen i 1893. Fra august 1893 var han frivillig i den kejserlige krigsmarine og blev efter kort tid forfremmet til "Marine Sanitätsrat 2. Klasse «. Efter at være vendt hjem fra et togt til Afrika, der varede over 20 måneder, blev han forfremmet til "Marine Assistensarzt 1. Klasse«. Fra 1. dec. 1896 var han udstationeret på flådebasen $\mathrm{i}$ Wilhelmshaven. Han søgte og fik sin afsked fra marinen med virkning fra 12. april 1897. Det var således den forste civile stilling, han tiltrådte på Rømø i maj 1897.
7. Otto Rud. Heinrich Horn (1848-1916) var født i Mecklenburg. Som ung student deltog han i den Tysk-Franske krig 1870/71. Efter endt uddannelse kom han til Tønder i 1880 . Horn siges at have været meget selskabelig anlagt. Han deltog i mange muntre lag i sin uniform fra krigen. I 1900 blev han Sanitätsrath.

8. Jes Riis (1859-1915) var født i Bodum lidt nord for Aabenraa og havde taget studentereksamen i Haderslev. Han praktiserede i Højer fra 1885. Han var en af grundlæggerne af »Tondernscher Ärzteverein«. Riis alternerede med den anden læge i Højer, Johann Friedrich Kühl (1861-1932), med at passe de patienter, der var indlagt på det lille sygehus i Højer.

9. Ludvig Otto Popke var født i Colmar i Elsass og havde promoveret i Halle i 1883. Hans interesse var især kvinde- og fødselssygdomme. Han havde praktiseret på den vestfrisiske ø Spikeroog og havde derefter, indtil han tiltrådte stillingen på Rømø, en stilling i Stettin.

10. Simon Oskar Eduard Rafalski havde overtaget apoteket i Skærbæk 1897 og solgte det i 1910. Herefter var han i en kortere periode amtsforstander i Skærbæk og senere i Rødding. Efter Genforeningen overtog han et apotek i Kiel. Han var meget aktiv i foreningsarbejdet og var $i$ en periode formand for apotekerforeningen i Schleswig-Holstein.

11. Rømø Amtsforstander arkiv, 298, Sager vedr. Læger paa Rømø. Skrivelse fra Landråd Rogge til Amtsforstanderen i Bredebro af 13.10.1904.

12. Theodor August Gerber var født i Westfalen den 1 . august 1840 og havde, som det var for vane for tyske medicinstuderende, studeret ved flere universiteter. Han havde således studeret medicin i Bonn, Würzburg og Berlin, hvor han 1863 blev læge. Han havde derpå virket som læge i Wöhrden i Ditmarsken. Han kom til Rømø fra en stilling på øen Føhr.

13. Loven om sundhedskommissioner blev udstedt i 1899, men for Schleswig - Holstein kom der forst i 1901 en »Geschäftsanweisung " gengivet $i$ 
Amtsblatt der Königlichen Regierung für Schleswig 1901:104. Af denne fremgår det, at kommuner med under 5000 indbyggere ikke nødvendigvis skulle have sundhedskommissioner, men såfremt landråden anså det for hensigtsmæssigt, skulle dette ske. I flg. $\$ 10$ omfattede sundhedskommissionens tilsyn også offentlige badeog svommehaller. Sundhedskommissionen for Romø blev efter opfordring af landrăd Rogge etableret i 1904. Den skulle bestå af forstanderen for Kongsmark Kommune, repræsentanter for badet i Lakolk foruden 1-2 medlemmer. Kommissionen refererede til kredslægen. Foruden hygiejniske bestemmelser, som var meget relevante, var der også bestemmelser for, hvordan et badested skulle indrettes og det skulle drives ud fra et sæedeligt synspunkt. Man forlangte således bl.a., at kvinder skulle have gensidig afskærmede omklædningsrum og der skulle være separat adgang for konnene til vandet. Endvidere måtte mand og kvinder først mødes, når de var $\mathrm{i}$ vandet. Der var bestemmelser for, hvordan man skulle være påklædt ved badningen og børn og unge mennesker måtte ikke betræede badestedet uden voksen ledsager. I et indlæg i Ugeskrift for Læger 1923 giver den tidligere Kreisarzt i Haderslev dr. Hansen udtryk for, at lovgivningen vedrorende sundhedskommissioner i Tyskland i allerhøjeste grad også var anvendelig i Danmark, hvor der dengang slet ingen kontrol var med de hygiejniske forhold omkring offentlige badesteder. Ugeskrift for Læger 1923: 83: 28; 944.

14. I "Ärztlicher Central-Anzeiger" nr. 16, 1906 er stillingen som ølæge beskrevet. Der står oversat til dansk: »Stillingen som læge på nordsøøen Rømø, Kreds Tønder, Regierungsbezirk Schleswig onskes besat snarest grundet den hidtidige læges sygdom. Den faste lon udgør 2000 Mark foruden indtægter fra lægehonorar til beboerne og den fortjeneste, der kan opnås ved salg af medicin fra medicinudsalget. Øen har iflg. den sidste folketælling 832 indbyggere. Desuden er der ansatte og ba- degæster ved badet i Lakolk. Det er ikke nødvendigt at holde hestekøretøj. Nybygget bolig står til rådighed, årlig leje 450 Mark. Ansøgning indeholdende en kort levnedsbeskrivelse med oplysning om militær lobebane og religion, tilligemed en afskrift af diverse eksamensbeviser bedes sendt til amtsforstanderen på Rømø巛.

15. Moritz, Eduard: Die Nordseeinsel Röm, 1903: 48.

16. Moritz, Eduard: Die Nordseeinsel Röm, 1903: 50. Det skal dog nævnes, at tallene også omfatter de personer, der overnattede på Römerhof og kroen i Havneby.

17. Japsen G.: Pastor Jacobsen fra Skærbæk og hans foretagender. Aabenraa 1980: 95.

18. Japsen, G.: Pastor Jacobsen fra Skærbæk og hans foretagender. Aabenraa 1980: 156.

19. Japsen, G.: Pastor Jacobsen fra Skærbæk og hans foretagender. Aabenraa 1980: 87.

20. Tønder Landrådsarkiv, 290. Medicinalvæesen - kødsyn: M 105: skrivelse af 15. juni 1906.

21. Tønder Landrådsarkiv, 290. Medicinalvæsen - kødsyn: M 105: skrivelse fra Voswinkel til landråd Rogge dateret 19. juli 1906 .

22. Tønder Landrådsarkiv, 290. Medicinalvæsen - kødsyn: $M$ 105: skrivelse fra Voswinkel til amtsforstander Freytag af 23. august 1906.

23. Tønder Landrådsarkiv, 290. Medicinalvæsen - kødsyn: M 105: skrivelse fra Nordseebad Lakolk GmbH. til landråden i Tønder af 17. april 1907.

24. Tønder Landrådsarkiv, 290. Medicinalvæsen - kødsyn: M105: skrivelse fra Landråd Rogge til Voswinkel af 18 . Juli 1907.

25. Tønder Landrådsarkiv, 290. Medicinalvæesen - kødsyn: M105: skrivelse fra Voswinkel til landråd Freytag dateret den 18. juli 1907.

26. Den første sammenslutning af tyske læger skete i form af Deutscher Arztevereinsbund i 1872 i Leipzig.

27. Tønder Landrådsarkiv 290. Medicinalvæsen - kødsyn: M 105: skrivelse fra Voswinkel til Regierungspräsidenten i Schleswig af 28. juli 1907. 
28. Tønder Landrådsarkiv, 290. Medicinal - kødsyn: M 105: skrivelse fra Voswinkel til landråden dateret 30 . juli 1908.

29. Tønder Landrådsarkiv, 290. Medicinal - kødsyn: M 105: skrivelse fra Voswinkel til landråden dateret 14 . august 1908.

30. Tønder Landrådsarkiv, 290. Medicinal - kødsyn: M 105: skrivelse fra lægesammenslutningen som er meget omfattende, dateret d. 31.8.1907.

31. Tønder Landrådsarkiv, 290. Medicinal - kødsyn: M 105: skrivelse til landråd Rogge dateret 16. august 1908.

32. Tønder Landrådsarkiv, 290. Medicinal - kødsyn: M 105: skrivelse til kommuneforstander Thye dateret 25 . august 1908.

33. Tønder Landrådsarkiv, 290. Medicinal - kødsyn: M 105: skrivelse fra regeringspræsidenten $i$ Schleswig til landråden i Tonder dateret 9. sept 1908.

34. Tønder Landrådsarkiv, 290. Medicinal - kødsyn: M 105: skrivelse dateret 9. september 1908.

35. Tønder Landrådsarkiv, 290. Medicinal - kødsyn: M 105: skrivelse fra landråd Rogge til Voswinkel dateret 12. okt. 1908.

36. Rømø Amtsforstander arkiv, 301: Sager vedr. Læger paa Rømø. Skrivelse fra landråd Rogge til Voswinkel af 5. marts 1909. 